\title{
ROLA ŚWIADOMEJ ZGODY RODZICÓW W OPIECE NAD NOWORODKAMI NA GRANICY ZDOLNOŚCI DO PRZEŻYCIA ${ }^{1}$
}

\author{
- Paweł Łuków -
}

\begin{abstract}
Abstrakt: Artykuł analizuje stosowanie standardu najlepiej pojętego interesu w opiece medycznej nad wcześniakiem na granicy zdolności do przeżycia. Stawia tezę, że jeżeli decyzje rodziców opierają się na rzetelnej lekarskiej ocenie stanu klinicznego i rokowania ich dziecka oraz nie wynikają z przesądów lub uprzedzeń, to profesjonaliści medyczni są zobowiązani respektować świadomą zgodę rodziców, nawet jeśli nie podzielają ich opinii. Profesjonaliści mogą kierować się przede wszystkim oceną kliniczną stanu i rokowania noworodka w ocenie jego interesów. Szczególne osobiste zaangażowanie rodziców w decyzję, wyznawane przez nich wartości oraz znany im rodzinny kontekst możliwej przyszłości ich dziecka czyni ich ocenę jego interesu istotnie bardziej wiarygodną od opinii innych podmiotów zaangażowanych w sprawę.
\end{abstract}

Słowa kluczowe: etyka medyczna, najlepiej pojmowany interes, skrajne wcześniaki, zgoda rodziców.

Published online: 15 March 2020

Rekomendacje dotyczące postępowania z noworodkami na granicy zdolności do przeżycia głoszą, że w pewnych sytuacjach rozstrzygające znaczenie dla tego, czy wszczynać resuscytację bądź też ograniczyć się do opieki paliatywnej, powinny mieć opinie rodziców, którzy mają kierować się najlepiej pojmowanym interesem noworodka. Takie wytyczne wydają się uzasadnione: w obliczu nadzwyczajnej niepewności diagnozy, lekarze mogą nie mieć wystarczających podstaw do podjęcia decyzji o dalszym postępowaniu, która byłaby oparta wyłącznie na rzetelnej wiedzy medycznej. Taka wiedza bowiem jest zawodna, a decyzja najczęściej dotyczy ludzkiego życia i śmierci. Dane zmieniają się wraz z postępem technologii medycznych, statystyki z wiodących lub zagranicznych ośrodków mogą nie mieć potwierdzenia w ośrodku, w którym dochodzi do przedwczesnego porodu, a ocena rokowania może stać się samospełniającą się przepowiednią².

Z punktu widzenia aspektów etycznych i prawnych postępowanie medyczne dotyczące noworodków na granicy zdolności przeżycia opiera się na zgodzie zastępczej

\author{
Paweł Łuków \\ Instytut Filozofii UW \\ Krakowskie Przedmieście 3 \\ 00-927 Warszawa \\ e-mai: p.w.lukow@uw.edu.pl \\ ${ }^{1}$ Artykuł powstał w ramach badań finansowanych przez Narodowe Centrum Nauki; grant nr \\ 2015/17/B/HS1/02390. \\ ${ }^{2}$ Byrne, Szyld, Kattwinkel (2008); Diekema, Mercurio, Adam (2011): 78; Ong (2013).
}


przedstawiciela ustawowego o wszczęciu resuscytacji lub o jej zaniechaniu i ograniczeniu interwencji do opieki paliatywnej. W literaturze dotyczącej takich decyzji można jednak spotkać zaskakująco niewiele rozważań na temat normatywnych aspektów udzielania świadomej zgody w opiece nad noworodkami na granicy zdolności do przeżycia oraz kryteriów podejmowania decyzji przez rodziców. Jest to okoliczność zaskakująca, ponieważ obok powszechnego uznania, że decyzje takie to $w$ istocie decyzje o życiu i śmierci noworodka, a więc o doniosłości moralnej najwyższej z możliwych, to szczegółowej refleksji normatywnej nad podejmowaniem takich decyzji przez rodziców (w zakresie, jaki jest dla nich możliwy) niemal nie ma. Badacze niejednokrotnie wszechstronnie i dogłębnie omawiają doniosłość decyzji, jej trudność i związaną z nią dużą niepewność oraz jej następstwa etyczne ${ }^{3}$. Zwykle podkreślają potrzebę partnerstwa profesjonalistów medycznych z rodzicami i wspólnego podejmowania decyzji. Jednak raczej rzadko i w ograniczonym zakresie odnoszą te obserwacje i rekomendacje do tej części decydowania o losach noworodków na granicy zdolności przeżycia, która przypada w udziale rodzicom.

To przeoczenie jest zaskakujące dlatego, że problem decyzyjny może wyglądać inaczej z punktu widzenia lekarza czy pielęgniarki, a inaczej z perspektywy rodziców. Racje, którymi będą się kierować profesjonaliści medyczni zaangażowani w opiekę nad noworodkiem, mogą być inne od względów, które biorą pod uwagę rodzice. Także wtedy, gdy i jedni, i drudzy rozpatrują te same okoliczności, inaczej mogą one wpływać na rodziców, a inaczej na personel medyczny, ze względu na ich odmienne usytuowanie egzystencjalne. $Z$ tego powodu może zaistnieć potrzeba, aby rekomendacje dotyczące podejmowania decyzji, względów, które należy brać pod uwagę i sposobu ich rozważania, były inne wtedy, gdy ich adresatami są profesjonaliści medyczni, a inne, gdy są nimi rodzice.

W niniejszym artykule zajmę się świadomą zgodą rodziców na postępowanie medyczne w odniesieniu do noworodków na granicy zdolności do przeżycia. Pokażę, że ze względu na egzystencjalne usytuowanie rodziców, których decyzje rozstrzygają o życiu i śmierci w warunkach ogromnej niepewności rokowania, kryteria podejmowania decyzji o postępowaniu medycznym stosowane przez rodziców w porównaniu z tymi, którymi winni kierować się profesjonaliści medyczni, muszą być istotnie różne, nawet jeżeli w obydwu wypadkach określane są zbiorczo jako najlepiej pojmowany interes (best interests) noworodka. Istnieje potrzeba przemyślenia na nowo standardu, na którym winna opierać się zgoda rodziców na postępowanie z noworodkami na granicy zdolności przeżycia. Przyjęte wyobrażenia dotyczące zgody zastępczej wydawanej przez rodzica na podstawie oceny najlepiej pojmowanego interesu pacjenta zbyt często mogą wprowadzać w błąd i rodzić niepotrzebne konflikty między profesjonalistami medycznymi a rodzicami zwłaszcza wtedy, gdy w opinii rodziców najlepszym postępowaniem dla ich dziecka będzie niewszczynanie lub zaprzestanie agresywnego leczenia.

Swoją argumentację przedstawię następująco. Najpierw wskażę, że dominujące obecnie wytyczne w opiece nad noworodkiem na granicy zdolności do przeżycia wymagają w pewnych wypadkach, aby w decyzjach o postępowaniu z noworodkiem

\footnotetext{
${ }^{3}$ Kipnis (2007); Lantos, Meadow (2006).
} 
rozstrzygała opinia rodziców. Zarazem zarówno profesjonalistom medycznym, jak i rodzicom zaleca się stosowanie $w$ tych decyzjach standardu najlepiej pojmowanego interesu noworodka, co rodzi pytanie, dlaczego ten sam standard miałby dawać inne wyniki wtedy, gdy stosują go rodzice, a inne wtedy, gdy korzystają z niego profesjonaliści medyczni. Następnie, odwołując się do obserwacji dotyczących sytuacji egzystencjalnej rodziców noworodka na granicy zdolności do przeżycia, przedstawię specyfikę perspektywy rodziców w używaniu standardu najlepiej pojmowanego interesu dziecka po to, aby wskazać zakres ważności świadomej zgody rodziców na postępowanie medyczne. Na tym tle pokażę relacje między zaleceniami lekarskimi a decyzjami rodziców. Będę twierdził, że jeżeli decyzje rodziców opierają się na rzetelnej lekarskiej ocenie stanu klinicznego i rokowania ich dziecka oraz nie są kierowane uprzedzeniami, profesjonaliści medyczni są zobowiązani respektować świadomą zgodę rodziców, nawet jeżeli nie podzielają ich opinii. Konkluzja ta zgodna jest ze stanowiskiem, które potrzebę zwiększenia roli rodziców w decydowaniu o losach noworodka na granicy zdolności do przeżycia opiera na niepewności ${ }^{4}$ Docenia przy tym odmienność sytuacji egzystencjalnej rodziców, która uzasadnia ich większą i bardziej aktywną rolę (o ile sobie tego życzą) w tym procesie decyzyjnym, niż to się na ogół dzieje w praktyce klinicznej. Dzięki zwiększeniu ich roli rodzice mogą lepiej wypełniać swoje etyczne i prawne obowiązki rodzicielskie.

\section{Rola rodziców w podejmowaniu decyzji o losach dziecka}

Pożądany stopień zaangażowana rodziców w podejmowanie decyzji o postępowaniu medycznym z noworodkami na granicy zdolności do przeżycia bywa przedmiotem rozbieżnych opinii. Model dominujący zakłada, że rodziców należy bezpośrednio włączać $\mathrm{w}$ podejmowanie decyzji, oddając $\mathrm{w}$ ich ręce kluczowe rozstrzygnięcia w zakresie, w jakim mogą je podjąć. Stanowisko alternatywne, obecne np. we francuskiej praktyce neonatologicznej, angażuje rodziców w podejmowanie decyzji pośrednio, przez wysłuchiwanie i branie pod uwagę ich opinii; decyzje podejmują jednak profesjonaliści medyczni ${ }^{5}$. Jako argument na rzecz takiego postępowania zwykle wskazuje się potrzebę oszczędzania rodzicom cierpień związanych z decydowaniem o losach ich dzieci oraz minimalizowanie ich poczucia winy w wypadku śmierci noworodka ${ }^{6}$. Środowiska regulacyjnego przyjaznego takiej praktyce dostarcza tzw. prawo Leonettiego z 2005 r., które uprawnia lekarza do podejmowania decyzji po zasięgnięciu opinii osoby zaufania (personne de confiance) lub rodziny oraz w następstwie kolegialnego omówienia sytuacji chorego ${ }^{7}$.

Stanowisko jedynie pośrednio włączające rodziców w podejmowanie decyzji o postępowaniu medycznym wdrażanym u ich dziecka nie zgadza się z etycznymi i prawnymi standardami postępowania lekarza na podstawie świadomej zgody pacjenta lub jego przedstawiciela oraz sprawowania przez rodziców pieczy rodzicielskiej. Lekarz udziela świadczeń zdrowotnych na podstawie i w granicach upoważnienia

\footnotetext{
${ }^{4}$ Kipnis (2007).

${ }^{5}$ Orfali (2004).

${ }^{6}$ Bourillon, Dehan, Beaufils, Fournier (1986); Dehan (1997).

${ }^{7}$ Code de la santé publique. Version consolidée au 12 mars 2018, art. L1110-5-2 i art. L1111-11.
} 
go przez pacjenta lub jego przedstawiciela ustawowego. Etyczną i prawną instytucją, w której dochodzi do udzielenia tego upoważnienia, jest świadoma zgoda ${ }^{8}$. Poza pewnymi wyjątkami (np. sytuacje nagłe ${ }^{9}$; decyzja sądu opiekuńczego ${ }^{10}$ ) działanie lekarza bez świadomej zgody pacjenta lub jego przedstawiciela ustawowego jest naruszeniem zasad etyki lekarskiej ${ }^{11}$ i przestępstwem ${ }^{12}$. Zwykle przedstawicielami ustawowymi pacjentów pediatrycznych są ich rodzice ${ }^{13}$. W ramach sprawowania pieczy rodzicielskiej ${ }^{14}$ mają oni obowiązek i prawo podejmowania decyzji oraz działania dla dobra dziecka ${ }^{15}$.

Do wykonywania pieczy rodzicielskiej należy rozstrzyganie (decydowanie) o istotnych sprawach dziecka, wśród których znajdują się sprawy związane z jego zdrowiem. Stąd rodzice mają nie tylko prawo, ale i obowiązek podejmowania decyzji o tym, jaką opiekę medyczną zapewnia się ich dzieciom przez udzielanie na tę opiekę świadomej zgody, tj. zgody opartej na informacji o stanie zdrowia, rokowaniu, możliwościach terapeutycznych itd., uzyskanej od profesjonalistów medycznych ${ }^{16}$. Termin "zgoda” obejmuje zarówno decyzję o wszczęciu lub kontynuacji czynności medycznych, jak i o niepodejmowaniu ich lub zaprzestaniu ${ }^{17}$. Aby zgoda rodziców była wiążąca (tj. by nie miała charakteru tzw. zgody blankietowej), informacja, na której się opiera, nie może być ogólnikowa. Dopełnienie etycznego i prawnego obowiązku udzielenia rodzicom informacji stanowi znaczne wyzwanie dla profesjonalistów medycznych dążących do minimalizacji cierpienia rodziców związanego z ciężarem decyzji i ewentualnym poczuciem winy w wypadku niepomyślnego wyniku leczenia. Wymaga zatem odpowiedniej wrażliwości i umiejętności.

Powinnościom prawnym i etycznym wynikającym z pełnienia roli rodzica odpowiadają oczekiwania rodziców, którzy w znaczącej większości, i jak się wydaje często pomimo różnic kulturowych, uważają, że to oni powinni podejmować rozstrzygające decyzje o życiu i śmierci noworodków, ponieważ stanowi to ich obowiązek ${ }^{18}$. Moralnej konieczności dopełnienia tej powinności nie osłabia dążenie do minimalizowania cierpienia rodziców związanego z podejmowaniem tak ważkich decyzji lub poczucia winy bądź żalu ${ }^{19}$.

W ramach korzystania ze swoich praw i wypełniania swoich obowiązków rodzicom nie wolno podejmować decyzji, które szkodzą dziecku lub żądać od profesjonalistów medycznych działań sprzecznych z prawem, jak np. leczenia niezgodnego ze

\footnotetext{
${ }^{8}$ KEL (2004) art. 15 ust. 1; U.p.p. art. 16; U.z.l. art. 32.

${ }^{9}$ KEL (2004) art. 15 ust. 3; U.z.l. art. 33.

${ }^{10}$ U.z.l. art. 32 ust. 2.

${ }^{11}$ KEL (2004) art. 15 ust. 1.

${ }^{12}$ K.k. art. 192.

${ }^{13}$ K.r.o. art. 98.

${ }^{14}$ K.r.o. art. 92.

${ }^{15}$ K.r.o. art. $95 \S 3$.

${ }^{16}$ U.p.p. art. 17 ust. 2; U.z.l. art. 32 ust. 2.

${ }^{17} \mathrm{~W}$ dalszej części terminy „zgoda rodziców” i „decyzja rodziców” będą używane zamiennie. Określenia te będą się odnosiły zarówno do decyzji o wszczęciu lub kontynuacji postępowania medycznego (zwykle określanej jako zgoda), jak i o ich niepodjęciu lub zaprzestaniu (zwykle nazywanej sprzeciwem).

${ }_{18}$ Brosig, Pierucci, Kupst, Leuthner (2007); Nguyen, Ho (2013).

${ }^{19}$ McHaffie, Lyon, Hume (2001).
} 
wskazaniami aktualnej wiedzy medycznej lub zasadami etyki lekarskiej ${ }^{20}$. Świadoma zgoda rodziców nie może więc autoryzować lub wymagać od profesjonalistów działań, które powodują u dziecka dające się przewidzieć i uniknąć cierpienia, bądź zaprzestania działań przynoszących dziecku ewidentne korzyści terapeutyczne. Etyczny i prawny standard postępowania przez lekarzy na podstawie i w granicach świadomej zgody rodziców ma zastosowanie także w opiece nad noworodkami na granicy zdolności do przeżycia: rodzice udzielają świadomej zgody zastępczej na postępowanie medyczne dotyczące ich dziecka.

Etykietka „zgoda zastępcza” może być myląca. Rodzic wyrażający zgodę na określoną interwencję dosłownie nie zastępuje noworodka w roli osoby podejmującej decyzję, chociaż go reprezentuje. O ile w wypadku osób, które w następstwie choroby lub okoliczności prawnych nie są w stanie podejmować dotyczących ich decyzji, zgoda zastępcza jest aktem dokonywanym w zastępstwie kogoś, kto w przeszłości był zdolny do wydania zgody, to u noworodka okoliczność ta nie zachodzi. Noworodek nigdy nie mógł podejmować decyzji, podobnie jak osoby od urodzenia niepełnosprawne intelektualnie w stopniu głębokim. Jednak w odróżnieniu od tych ostatnich, których dotychczasowe zachowania i styl życia pozwalają na rekonstrukcję przynajmniej części tego, co może stanowić ich zindywidualizowane dobro, w odniesieniu do noworodka brakuje podstaw do rekonstruowania jego oczekiwań lub preferencji, ponieważ nie ma on porównywalnie bogatej biografii.

Z powyższych względów w odniesieniu do noworodków nie można nawet w części (tak jak to jest możliwe w przypadku osób od urodzenia poważnie upośledzonych intelektualnie) zastosować standardu osądu zastępczego (substituted judgment standard), kiedy to zadanie decydenta polega na rekonstrukcji preferencji, oczekiwań, czy zdolności do czerpania przez pacjenta satysfakcji z określonych zdarzeń lub przeżyć na podstawie znajomości jego wypowiedzi, zachowań lub biografii. Decydowanie o postępowaniu wobec dziecka, które właśnie przyszło na świat, nie może dać zindywidualizowanego wyniku, jakim jest unikalne dobro konkretnego pacjenta odniesione do jego doświadczeń, oczekiwań lub zdolności, mimo najlepszych chęci, wiedzy i umiejętności osób podejmujących decyzję. Właściwym sposobem decydowania w odniesieniu do pacjenta, który nie ma biografii lub którego biografia nie jest znana, jest - jak głoszą bioetyczne autorytety ${ }^{21}$ - kierowanie się standardem jego najlepiej pojmowanego interesu.

\section{Standard najlepiej pojmowanego interesu w opiece nad noworodkiem}

Istotą zastosowania standardu najlepiej pojmowanego interesu pacjenta jest ocena korzyści i ciężarów związanych z rozważanym postępowaniem medycznym. Określenie interesu pacjenta jest często bardzo trudnym zadaniem, ponieważ wymaga uwzględnienia czynników, które już na pierwszy rzut oka wydają się nieporównywalne, a ponad to trudno jest im przypisywać miary. Z tego względu standard najlepiej pojmowanego interesu pacjenta jest elastyczny, co pozwala brać pod uwagę wiele rozmaitych wzglę-

\footnotetext{
${ }^{20}$ Por. U.z.l. art. 4.

${ }^{21}$ Np. Diekema et al. (2011): 78-79; Szewczyk (2010).
} 
dów; ta elastyczność bywa traktowana przez jednych jako jego zaleta ${ }^{22}$, ale przez innych jako wada ${ }^{23}$.

Standard najlepiej pojmowanego interesu nie jest precyzyjny i dopuszcza różne interpretacje w zależności od kontekstu (np. spory o prawo do opieki nad dzieckiem w postępowaniach rozwodowych czy decyzje o postępowaniu medycznym), a także w ramach jednego kontekstu (np. przez sądy) dopuszcza odmienne interpretacje w zależności od tego, kto go używa ${ }^{24}$. Buchanan i Brock uważają, że standard ten wymaga ustalenia korzyści netto dla pacjenta związanych z każdą dostępną opcją postępowania. Każdej z opcji należy przypisać właściwą wagę w zależności od względnej doniosłości interesów, którym ta opcja sprzyja lub którym szkodzi. Następnie od tej sumy korzyści należy odjąć wszystkie koszty dla pacjenta związane z każdą z opcji, by wybrać opcję, której wartość netto jest najwyższa ${ }^{25}$. Wytyczne amerykańskiej Prezydenckiej Komisji ds. Badania Etycznych Problemów w Medycynie oraz w Badaniach Biomedycznych i Behawioralnych są nieco mniej ogólne. Komisja rekomenduje, aby przy szacowaniu najlepiej pojmowanego interesu osoby niezdolnej do podejmowania decyzji brać pod uwagę takie czynniki jak ulga w cierpieniu, zachowanie lub przywrócenie funkcji, jakość i długość życia, zdolność do odczuwania satysfakcji w przyszłości czy możliwość osiągnięcia zdolności do decydowania o sobie ${ }^{26}$.

Powyższe charakterystyki najlepiej pojmowanego interesu pacjenta mają charakter obiektywizujący ${ }^{27}$. Kluczowe czynniki wpływające na interesy pacjenta odnoszą się do jego stanu klinicznego i przewidywanych konsekwencji tego stanu w połączeniu z dostępnymi opcjami postępowania. Chociaż uwzględnia się tu wpływ tych czynników na stan psychiczny pacjenta, to nie obejmują one jego rzeczywistych bądź hipotetycznych preferencji czy oczekiwań. Drugą cechą charakterystyczną szacowania najlepiej pojmowanego interesu pacjenta jest perspektywa konsekwencjalistyczna, tj. ocena zasadności dostępnych interwencji na podstawie tego, jakie są ich przewidywane skutki dla zdrowia fizycznego lub psychicznego pacjenta. Trzecią własnością tego standardu jest neutralność co do teorii wartości, która ma dostarczać kryteriów oceny dostępnych opcji działania. Nie mówi on, czy w ocenie skutków interwencji liczy się to, jak wpłynie ona na stany psychiczne dziecka (np. odczuwanie satysfakcji, na tyle, na ile będzie to możliwe), czy też realizacja określonych wartości uznanych za wymagające realizacji lub respektowania (np. zdolność wchodzenia w znaczące relacje z innymi) ${ }^{28}$. Osoby stosujące ten standard mogą wobec tego ograniczać swoją ocenę do czynników wyłącznie klinicznych bądź też w sposób dla nich samych niejawny angażować swoje przekonania aksjologiczne. Ta neutralność aksjologiczna ujawnia się m.in. w różnicach między profesjonalistami medycznymi w stosowaniu standardu ${ }^{29}$.

\footnotetext{
${ }^{22}$ Np. Herring (2005).

${ }^{23} \mathrm{~Np}$. Elster (1987).

${ }^{24}$ Elliston (2007): rozdz. I.

25 Buchanan, Brock (1989): 123.

${ }^{26}$ President's Commission for the Study of Ethical Problems in Medicine and Biomedical and Behavioral Research (1983): 135.

27 Archard (2003): 43-50.

${ }^{28}$ DeGrazia (1995).

${ }^{29}$ Weir, Evans, Coughlin (2011).
} 
W praktyce perinatologii czynniki brane pod uwage przy szacowaniu interesów pacjenta będą miały niejednorodny charakter, który nie wyczerpuje upraszczającej dychotomii między jakością a świętością życia. Można założyć, że w znakomitej większości przypadków czynniki te obejmą szanse przeżycia noworodka, ból spowodowany resuscytacją lub też nieskutecznym leczeniem oraz korzyści i ciężary związane z możliwymi niesprawnościami lub chorobami, które mogą wystąpić w dalszym życiu dziecka. Aby bardziej precyzyjnie oszacować interesy noworodka niezbędne może się okazać uwzględnienie warunków, w jakich dziecko będzie wzrastało i do odczuwania jakich przyjemności będzie zdolne.

Tak też głoszą rekomendacje Nuffield Council on Bioethics. Członkowie tej rady zalecają, aby w decyzjach o wszczęciu, zaprzestaniu bądź zaniechaniu leczenia brać pod uwagę możliwość znaczącego przedłużenia życia noworodka, wielkość jego przewidywanych cierpień i dostępne możliwości ich minimalizacji, zdolność do samodzielnego przeżycia oraz uzyskania właściwej opieki poza szpitalem, zdolność do nawiązywania w przyszłości relacji z innymi ludźmi i doświadczania przyjemności, a także opinie rodziców na ten temat. Tego rodzaju czynniki należy uwzględnić w szacowaniu proporcji między przewidywanymi ciężarami i korzyściami dla noworodka. Szczególną uwagę należy poświęcić opiniom rodziców dotyczącym zarówno interesów samego dziecka, jak i ich opinii w kwestii relacji między tymi ciężarami i korzyściami ${ }^{30}$. W centrum uwagi przez cały czas pozostaje noworodek i jego interesy ${ }^{31}$.

W stosowaniu standardu najlepiej pojmowanego interesu noworodka główną rolę odgrywają zatem czynniki i przewidywania związane z oceną medyczną stanu pacjenta oraz wpływu jego otoczenia na jego dalsze losy. Nie ulega wątpliwości, że jest to narzędzie, którym mogą się posługiwać profesjonaliści medyczni po zebraniu informacji o pacjencie i warunkach, w jakich może żyć w przyszłości. Do zastosowania tego standardu niepotrzebna jest wiedza, która odwoływałaby się do preferencji lub oczekiwań określonego chorego. Wiedza i kompetencje profesjonalistów medycznych pozwalają im ocenić, jaki jest stan kliniczny i rokowania pacjenta, a także (w stopniu nie gorszym niż inne osoby) wpływ na noworodka potencjalnych warunków jego życia. Osoby te nie muszą (bo i nie mogą) wiedzieć, jaki standard życia będzie dla dziecka akceptowalny oraz jakie ciężary związane z niepełnosprawnością lub chorobą będą dla niego akceptowalne, a jakie nie do zniesienia.

Mimo to rekomendacje dotyczące postępowania z noworodkami na granicy zdolności do przeżycia w pewnych sytuacjach przenoszą ciężar decydowania na rodziców. Na przykład cytowana już Nuffield Council zaleca, aby w odniesieniu do 23-tygodniowych noworodków dawać pierwszeństwo życzeniom rodziców odnośnie do decyzji o wszczynaniu resuscytacji lub leczeniu na oddziale intensywnej terapii, natomiast w wypadku noworodków urodzonych w 22 tygodniu, resuscytacja jest rekomendowana tylko w odpowiedzi na ponawiane nalegania rodziców poprzedzone wszechstronną rozmową z pediatrą ${ }^{32}$. Podobne wskazówki - choć bez odwołań do standardu najlepiej pojmowanego interesu noworodka - znajdowały się w polskich Rekomendacjach doty-

\footnotetext{
${ }^{30}$ Nuffield Council on Bioethics (2006): xxii-xxiii, 15.

${ }^{31}$ Nuffield Council on Bioethics (2006): xvii, 15.

${ }^{32}$ Por. Diekema et al. (2011): 79; Nuffield Council on Bioethics (2006): xxi, 155-156.
} 
czących postępowania z matka oraz noworodkiem urodzonym na granicy możliwości przeżycia z uwzględnieniem aspektów etycznych z 2011 r. W odniesieniu do noworodków w wieku ciążowym 23 0/7-23 6/7 tygodni Rekomendacje zalecały: „w przypadku, gdy po przeprowadzonej wcześniej rozmowie z rodzicami nalegają oni, by podjąć resuscytację, należy podjąć działania resuscytacyjne i przewieźć noworodka do Oddziału Intensywnej Terapii", a w odniesieniu do noworodków urodzonych w 24 0/7-24 6/7 tygodni ciąży: „rekomendowane jest podjęcie działań resuscytacyjnych. Dalsze postępowanie zależne będzie od oceny stanu klinicznego, odpowiedzi na zabiegi resuscytacyjne i stanowisko rodziców" ${ }^{\prime 3}$. Późniejsza wersja Rekomendacji pt. Zasady postępowania w neonatologii przy podejmowaniu decyzji o objęciu opieka paliatywna uwzględniające racje etyczne z $2017 \mathrm{r}$. włącza rodziców w proces decyzyjny w mniejszym zakresie, głosząc wprost, że „osobą podejmującą decyzję jest lekarz", który bierze pod uwagę "postawę oraz przekonania rodziców"34, a ponadto zaleca dla noworodków w wieku ciążowym 23 0/7-23 6/7 tygodni opiekę paliatywną lub resuscytację „na życzenie rodziców lub jeżeli występują czynniki poprawiające rokowanie" 35 .

Na pierwszy rzut oka takie postępowanie jest zasadne z dwóch powodów. Po pierwsze, tam, gdzie wiedza medyczna nie pozwala ocenić, jaki rodzaj opieki będzie najlepiej służył interesom pacjenta, ponieważ trudno ocenić, czym dokładnie one są, uzasadnione wydaje się powierzenie decyzji rodzicom, którym osobiście zależy na powodzeniu czy dobru pacjenta. Ich przekonania można traktować jako względy dodatkowe, które wobec braku rozstrzygających racji na rzecz jednego z dostępnych kierunków postępowania mogą przechylić szalę w procesie decyzyjnym. Po drugie, w obliczu niezwykle wysokiej niepewności rokowania u noworodków na granicy zdolności do przeżycia - nawet jeśli względy, które należy brać pod uwagę przy szacowaniu najlepiej pojmowanego interesu pacjenta są znane - zdanie się na względy, które z punktu widzenia wiedzy medycznej mają charakter losowy, wydaje się na pierwszy rzut oka jedyną zasadną strategia decyzyjną.

Problematyczność takich rekomendacji ujawnia się jednak wraz z uświadomieniem sobie, że także rodzice powinni kierować się najlepiej pojmowanym interesem noworodka ${ }^{36}$. Jak jednak mogą zastosować tę samą dyrektywę, jeżeli nie była ona wystarczająco pomocna dla profesjonalistów medycznych, o których wolno założyć, że dysponują wiedzą pozwalającą im ocenić interesy dziecka? Jeżeli neonatolog lub zespół interdyscyplinarny nie są w stanie ocenić interesów noworodka i oddają decyzję w tej sprawie rodzicom, którzy powinni stosować tę samą dyrektywę - korzystając z tej samej wiedzy (dostarczonej im przez profesjonalistów medycznych) i w obliczu tej samej niepewności - to należy uznać, że wytyczne zakładają, iż stosowanie standardu najlepiej pojmowanego interesu noworodka generuje przypadkowe konkluzje, a wobec tego standard ten nie jest odpowiednim narzędziem decyzyjnym, bądź też że jest on wystarczająco dobrym narzędziem decyzyjnym, które może dać istotnie odmienne wyniki w zależności od tego, kto się nim posłuży.

\footnotetext{
33 Rutkowska (2011).

34 Polskie Towarzystwo Neonatologiczne (2017): 24.

35 Polskie Towarzystwo Neonatologiczne (2017): 22.

36 Nuffield Council on Bioethics (2006): 22-23.
} 


\section{Najlepiej pojmowany interes noworodka w perspektywie rodziców}

Taka konsekwencja rekomendacji może być niepokojąca. O ile pewne odmienności opinii rozsądnych osób stosujących tę samą dyrektywę namysłu są zrozumiałe i dopuszczalne (np. w ocenie klinicznej stanu pacjenta czy na gruncie prawa), to taka różnica nie powinna być zbyt wielka, a przynajmniej nie powinna mieć fundamentalnie odmiennych konsekwencji. W większości przypadków dopuszczalna jest różnica oceny między sądami dysponującymi tym samym materiałem dowodowym, z których jeden uznaje, że osoba naruszająca prawo zasługuje na wyższy wymiar kary, a drugi, że kara ta winna być niższa. Analogicznie w medycynie. Dwóch równie kompetentnych specjalistów może się różnić w opiniach na temat właściwego postępowania terapeutycznego, lecz różnice między ich opiniami nie powinny być fundamentalne, a przynajmniej nie powinny przekładać się na takie różnice losów pacjenta jak życie lub śmierć. Tymczasem rekomendacje dotyczące decydowania o losie noworodków na granicy zdolności do przeżycia, które zalecają zarówno profesjonalistom medycznym, jak i rodzicom kierowanie się najlepiej pojmowanym interesem pacjenta, zdają się dopuszczać tak znaczącą różnicę w wynikach namysłu kierowanego tymi samymi wytycznymi. Omawiane oceny są podstawą decyzji, które w istocie rozstrzygają o życiu lub śmierci noworodka. Różnica nie jest zatem marginalna. Jest zasadnicza.

Aby zatem wytycznej wymagającej stosowania standardu najlepiej pojmowanego interesu w opiece nad noworodkami na granicy zdolności do przeżycia nie interpretować jako zachęty do pozbycia się przez specjalistów nierozstrzygalnego problemu i zrzucenia go na barki rodziców, którzy i tak znajdują się w niezwykle trudnej sytuacji, należy przyjąć albo że dane, jakie mają brać pod uwagę lekarze, istotnie różnią się od danych, na podstawie których decyzje mają podejmować rodzice, albo że standard najlepiej pojmowanego interesu dziecka nie jest jedynym kryterium, którym winni się posługiwać rodzice, bądź też że standard ten funkcjonuje inaczej wtedy, gdy korzystają z niego rodzice, a inaczej wtedy, gdy używają go profesjonaliści medyczni.

Takie wydaje się być stanowisko Nuffield Council głoszącej, że w ocenie interesów noworodka istotne mogą być życzenia i oczekiwania rodziców oraz wpływ przewidywanej choroby lub niepełnosprawności dziecka na jego rodzinę i jej zdolność do zapewnienia mu odpowiednich warunków rozwoju ${ }^{37}$. Znaczące jest jednak to, że odniesienie do życzeń i oczekiwań rodziców w ocenie najlepiej pojmowanego interesu noworodka, nie zostaje skontekstualizowane w sposób, który pozwalałby powiedzieć, kto powinien brać pod uwage życzenia i oczekiwania rodziców. Jeżeli bowiem życzenia te i oczekiwania mają brać pod uwagę zarówno profesjonaliści medyczni, jak i sami rodzice, to należy uznać, że zastosowanie standardu najlepiej pojmowanego interesu noworodka daje inne wyniki w zależności od tego, kto się nim posługuje, lub że dane o oczekiwaniach i życzeniach rodziców inaczej wpływają na końcowy wynik tej oceny w zależności od tego, kto z nich korzysta. Jeżeli tak, to standard najlepiej pojmowanego interesu noworodka jest zbyt niedookreślony, aby stanowić wiarygodny instrument podejmowania fundamentalnych decyzji o losach dziecka, bądź też oczekiwania i życzenia

$\overline{37}$ Nuffield Council on Bioethics (2006): xxii-xxiii. 
rodziców odgrywają inną rolę w procesie decyzyjnym, gdy standardem posługują się rodzice niż wtedy, gdy korzystają z niego profesjonaliści medyczni. Wtedy oczekiwania i życzenia rodziców mogą mieć rozstrzygające znaczenie dla losów dziecka.

Standard najlepiej pojmowanego interesu noworodka wzbudził wiele głosów krytycznych, które były przedmiotem wielu kompetentnych omówieńn ${ }^{38}$. Pomimo pewnych prób ${ }^{39}$, dotąd nie udało się wypracować zadowalających alternatyw wobec niego. Zapewne należy tu pójść za radą Arystotelesa, aby w badaniach dążyć do takiego stopnia dokładności, na jaki pozwala ich przedmiot. Ocena interesów noworodka musi włączać czynniki, które nie poddają się nieupraszczającym pomiarom i których względna waga w życiu dziecka jest często nie do przewidzenia. Z punktu widzenia procesu decyzyjnego, nieprecyzyjność standardu nie zmienia się wraz z tym, kto go w danym przypadku używa. Co więcej, jak dotąd nie powstał alternatywny standard decyzyjny ${ }^{40}$, który precyzją i zgodnością ze społecznie przeważającymi intuicjami etycznymi istotnie przewyższałby standard najlepiej pojmowanego interesu noworodka.

Z powyższych względów bardziej zasadna wydaje się hipoteza, według której te same czynniki uwzględniane w procesie decyzyjnym mogą odgrywać inną rolę lub mieć inną wagę, gdy decyzję podejmują profesjonaliści medyczni, a inną, gdy rodzice, a tym samym mogą prowadzić do różnych wniosków. Różnica ta może też wskazywać, dlaczego rozbieżne wnioski mogą być równie dobrze uzasadnione i żadna ze stron nie musi podlegać krytyce moralnej. Wtedy zasadne będzie przekazanie ostatecznej decyzji rodzicom tam, gdzie perspektywa medyczna nie pozwala rozstrzygnąć, jakie postępowanie będzie najlepsze.

Nie ulega wątpliwości, że zasadnicza odmienność sytuacji egzystencjalnej rodziców noworodka urodzonego na granicy zdolności do przeżycia od tej, w jakiej znajdują się lekarze czy pielęgniarki, będzie wpływać na postrzeganie przez nich sytuacji, w której się znaleźli i na dokonywane przez nich wybory. Można tu wskazać na dwie główne odmienności wynikające z faktu, że rodzice problem decyzyjny postrzegają z „krótkiego dystansu etycznego" ${ }^{\prime 1}$.

Po pierwsze, rodzice podejmują decyzje z punktu widzenia swoich własnych przekonań o wartościach i własnych oczekiwań, które zawsze mają niepowtarzalny kształt ze względu na unikalne biografie rodziców i ich wspólną historię. Ich oczekiwania w stosunku do dziecka podlegają wpływowi ich przekonań o tym, co czyni wartościową obecność dziecka w ich życiu, a także kształtuje ich stosunek do ogromnej niepewności rokowania, a przez to pozwala im ustalić (w stopniu, w jakim jest to możliwe w tak dramatycznej sytuacji), na jakie ciężary związane z opieką i wychowywaniem swojego dziecka są gotowi. Ze względu na ten unikalny kontekst i sposób pojmowania swojej sytuacji, przedwczesne narodziny dziecka rodzice będą traktować jako część ich życia, a nie jako coś, co tylko ma na ich życie wpływ. Ewentualne cierpienie dziecka, choroby lub niepełnosprawności, jego potencjał i ograniczenia będą musiały stać się c zęścią ich

\footnotetext{
38 Elliston (2007); Loretta M. Kopelman (1997); Mnookin (1975).

39 Shah (2013).

${ }^{40}$ Mnookin (1975): 282.

41 Duff (1987).
} 
przyszłej tożsamości, by obecną decyzję mogli uznać za trafną. I tylko oni, jeśli ktokolwiek, mogą ocenić, czy będą w stanie tę przyszłość zaakceptować.

Nie sposób oczekiwać, aby ktoś mógł zastąpić rodziców w roli tego, kto ocenia wagę i rozmiary korzyści i ciężarów, jakie ze względu na ich wartości staną się udziałem ich dziecka i, z konieczności, ich samych. Dzieje się tak nie dlatego, że rodzice mają jakiś uprzywilejowany dostęp do znajomości najlepiej pojmowanego interesu dziecka (empiria poucza, że taka teza jest zbyt często fałszywa), ale dlatego, że ich punktu widzenia nie można zastąpić jakimkolwiek innym bez uczynienia go punktem widzenia kogoś, kto ma inne doświadczenia, inne wartości i inne oczekiwania, a więc punktem widzenia mniej relewantnym lub zgoła niewłaściwym w sytuacji tych akurat rodziców.

Po drugie, urodzenie się obarczonego rozmaitymi obciążeniami dziecka najczęściej jest dla rodziców wydarzeniem niepowtarzalnym i trudnym do zrozumienia, ponieważ kwestionuje ono ich plany. Oczekiwanie narodzin dziecka to zwykle okres realizowania planu przyszłego życia ze zdrowym dzieckiem, które przychodzi na świat w określonym czasie. Przedwczesne narodziny dziecka i spowodowane nimi zagrożenia zaburzają rodzinną chronologię i zmieniają jej elementy składowe. Każą rodzicom w krótkim czasie przemyśleć na nowo swoje wyobrażenia o własnym życiu rodzinnym tak, by znowu stało się zrozumiałą całością, w której znajdą się przedwczesne narodziny ich dziecka. W procesie przebudowy narracji dotyczącej ich życia, rodzice będą musieli skonfrontować się ze swoimi wartościami i przekonaniami. Czasem ta konfrontacja może ich doprowadzić do postrzegania nieoczekiwanych narodzin dziecka jako czegoś, co ma wymiar moralny. W poszukiwaniu wyjaśnienia tego, co ich spotkało, mogą nawet uznać siebie za winnych lub powód do wstydu, ale mogą też potraktować swą sytuację jako wyzwanie. Mogą przedefiniować swoje wartości, co pozwoli im znaleźć się w nowych okolicznościach; możliwe jest również, że nie zdołają wypracować żadnej akceptowalnej dla siebie koncepcji swojego życia rodzinnego. Ponieważ konfrontacja z własnymi priorytetami moralnymi jest aktem na wskroś zindywidualizowanym, jest oczywiste, że jej wynik jest nie do przewidzenia i że nikt poza rodzicami nie dokona takiej samej oceny sytuacji, w której się znaleźli i tego, jak należy się w niej zachować.

Z pewnością pochopne byłoby zlekceważenie perspektywy rodziców. Doniosłość ich wyobrażeń o tym, w jakim stopniu ich przekonania o wartościach pozostawiają miejsce na określone korzyści i cierpienia ich dziecka wynika z tego, że rodzice i ich wartości oraz rodzina stanowią część zasobów dziecka, które mają decydujący wpływ na jego widoki na przyszłość ${ }^{42}$. Ponieważ rodzina stanowi naturalny system wsparcia dla dziecka, zwłaszcza dla dziecka z niepełnosprawnościami lub mającego szczególne potrzeby, istotne zagrożenie interesów któregokolwiek z członków rodziny - zarówno rodziców, jak i ich innych dzieci, a w pewnych wypadkach także i dalszej rodziny przekłada się na ryzyko dla dziecka. Nieuwzględnienie interesów innych członków rodziny może prowadzić do katastrofy emocjonalnej, małżeńskiej i finansowej ${ }^{43}$, która musi negatywnie wpłynąć także na dalsze losy dziecka. Nadanie priorytetu interesom noworodków na granicy zdolności do przeżycia musi zatem uwzględniać interesy ro-

\footnotetext{
42 Shaw (1977).

${ }^{43}$ Whitney (2005).
} 
dziny ${ }^{44}$, które są w zasadniczy sposób określane przez przekonania o wartościach oraz oczekiwania rodziców.

Powyższe uwagi wskazują, że decydowanie przez rodziców w sprawie noworodków na granicy zdolności do przeżycia oparte na standardzie najlepiej pojmowanego interesu może korzystać z tych samych danych, którymi dysponują profesjonaliści medyczni, lecz różnica punktu widzenia sprawia, że dane te będą inaczej funkcjonowały $\mathrm{w}$ procesie podejmowania decyzji. Interesy dziecka i rodziny będą rozważane nie z punktu widzenia względnie niezainteresowanej osobiście strony, która w przezwyciężaniu niepewności koncentruje się na "technicznych" danych obiektywizujących jej rozumienie stojących przed nią decyzji ${ }^{45}$, ale właśnie z perspektywy osobiście zaangażowanego za pośrednictwem wyznawanych wartości i przeżywanych emocji członka rodziny, który staje przed kluczową decyzją o losach jednego z jej członków i całej tej rodziny. Jego niepowtarzalny stosunek do sytuacji wspomagany wiedzą dostarczaną przez profesjonalistów medycznych może pozwolić na uwzględnienie w procesie decyzyjnym tego, co specyficzne dla konkretnego noworodka i jego zaplecza aksjologicznego, emocjonalnego i społecznego.

Nie oznacza to, że każdą decyzję rodziców o postępowaniu z noworodkiem na granicy zdolności do przeżycia należy zrealizować. Sam fakt bycia rodzicem nie gwarantuje trafności decyzji dotyczącej dziecka. Oznacza to jednak, że opinie i decyzje rodziców wymagają, by brać je pod uwagę poważnie. W szczególności, oznacza to, że przynajmniej niektóre decyzje rodziców niezgodne z tym, co za najlepsze dla noworodka uznałby zespół terapeutyczny, wymagają respektowania. Jest tak dlatego, że niektóre racje moralne na rzecz jakiegoś działania nie przemawiają do wszystkich, a równocześnie nie sposób uzasadnić tezy głoszącej, że wszyscy powinni te racje odrzucić. Tak jest w przypadku racji opartych na wartościach, które są ważne dla jednych, a mniej istotne dla innych. Natomiast inne racje opierają się na przekonaniach wartościujących, które wymagają odrzucenia przez wszystkich ${ }^{46}$, jak np. przesądy dyskryminujące ze względu na niepełnosprawność lub fałszywe przekonania o faktach ${ }^{47}$.

Decyzje oparte na racjach, o których nie można twierdzić, że winni je odrzucić wszyscy, powinny być respektowane przez profesjonalistów medycznych, natomiast racje, które powinni odrzucić wszyscy, podlegają krytyce i profesjonalistom nie wolno legitymizować opartych na nich decyzji. Na gruncie neonatologii byłoby np. niewłaściwe nierespektowanie decyzji rodziców o niepodejmowaniu resuscytacji wtedy, gdy dostępne interwencje medyczne są obarczone wysokim ryzykiem cierpienia dziecka i obiecują mu znikome lub żadne korzyści. Nie istnieją bowiem powszechnie podzielane racje, które jednoznacznie kazałyby uznać taką decyzję rodziców za błędną ${ }^{48}$. Zasadna i wymagana byłaby natomiast na przykład odmowa realizacji decyzji rodzica kierowanego uprzedzeniami wobec osób z niepełnosprawnościami.

\footnotetext{
${ }^{44}$ Nuffield Council on Bioethics (2006): 17.

45 Anspach (1993): rozdz. 3.

46 Scanlon (1998): 348-349.

47 Kopelman, Kopelman (2007).

48 Rhodes, Holzman (2014).
} 
Jeżeli powyższe argumenty są trafne, to standard najlepiej pojmowanego interesu noworodka ulega ważnej zmianie wtedy, gdy posługują się nim rodzice dziecka w porównaniu z jego funkcjonowaniem w rękach profesjonalistów medycznych. Gdy posługują się nim profesjonaliści medyczni, ma on głównie wymiar kliniczny, ewentualnie wzbogacony obecnym w tradycji medycyny nakazem walki o życie i raczej w niewielkim stopniu może uwzględniać specyfikę środowiska rodzinnego, warunków życia noworodka w jego rodzinie. Natomiast korzystający z tego standardu rodzice mogą umieścić informacje uzyskane od profesjonalistów w kontekście specyficznych warunków, w których pojawia się noworodek i jakie mogą mu zapewnić, w zależności od dalszego rozwoju wypadków, co może doprowadzić do określenia ich stosunku do niepewności rokowania. Rodzice dysponujący rzetelną informacją dostarczoną przez profesjonalistów medycznych mają bogatszy materiał do oceny szans ich dziecka na udane (czy choćby minimalnie udane) życie niż materiał, którym posługują się profesjonaliści. Przez osobiste zaangażowanie mogą zająć wiarygodną - choć niekoniecznie jednoznaczną i niepodlegającą zmianom w czasie - postawę wobec niepewności rokowania. Świadoma zgoda rodziców na postępowanie medyczne wobec ich dziecka może wtedy być bardziej wiarygodna od decyzji innych osób dlatego, że oparta jest na szerszej wiedzy umieszczonej w konkretnym kontekście.

Szacunki rodziców dotyczące interesów ich dziecka w celu udzielenia świadomej zgody będą się dokonywały z punktu widzenia ich przekonań o wartościach, które będą określać ich wyobrażenie o tym, jaki rodzaj życia i funkcjonowania dziecka uznają za dla niego pożądany lub minimalnie pożądany. Przez to, że będą dokonywane przez rodziców, szacunki te z konieczności będą uwzględniać ich własny potencjał emocjonalny i zaplecze społeczne, na jakie mogą liczyć w opiece nad dzieckiem. Przez to też będą mogli określić sposób radzenia sobie z niepewnością rokowania. Granice, w których będą mieściły się decyzje rodziców, będą wyznaczone przez informacje uzyskane od profesjonalistów medycznych na temat rokowania, jego prawdopodobieństwa oraz ciężarów i korzyści, jakie mogą być udziałem noworodka w przyszłości. Jest to szczególnie ważne ze względu na to, że oczekiwanie narodzin dziecka na ogół wiąże się z nadziejami, które mogą skłaniać rodziców do zbytniego optymizmu ${ }^{49}$, a przez to do niedoceniania niepewności rokowania. Świadoma zgoda rodziców musi opierać się na wiedzy o prawdopodobieństwach poszczególnych scenariuszy lub o nieznajomości tych prawdopodobieństw, a nie na samych nadziejach na zrealizowanie się najbardziej pomyślnego $\mathrm{z}$ nich ${ }^{50}$. W zakresie więc, $\mathrm{w}$ jakim decyzje rodziców nie stoją w sprzeczności z medycznymi szacunkami interesów noworodka, instytucja świadomej zgody bezwzględnie wymaga, aby profesjonaliści medyczni respektowali postanowienia rodziców.

Istotną konsekwencją przedstawionego stanowiska jest zmiana stopnia zaangażowania rodziców w proces podejmowania decyzji o losach ich dziecka na granicy zdolności do przeżycia. W przeciwieństwie do częstych praktyk, w których rodzice co najwyżej przystają na decyzje profesjonalistów medycznych ${ }^{51}$, a bywa, że są wręcz eliminowani

\footnotetext{
49 Szewczyk (2012).

50 Sinclair, Torrance (1995).

51 Anspach (1993): 87-110.
} 
$\mathrm{z}$ tego procesu ${ }^{52}$, proponowane podejście wymaga włączania rodziców w decydowanie w sposób dla nich możliwy. Świadoma zgoda rodziców na postępowanie medyczne w stosunku do noworodków na granicy zdolności do przeżycia może tym samym stać się częścią autentycznego partnerstwa rodziców i profesjonalistów medycznych.

\section{Zakończenie}

Powyżej wskazywałem trudności, z jakimi wiąże się stosowanie standardu najlepiej pojmowanego interesu pacjenta w opiece neonatologicznej w odniesieniu do noworodków na granicy zdolności do przeżycia. Standard ten ma dosyć ogólny charakter i dlatego wydaje się użyteczny zarówno dla profesjonalistów medycznych, jak i dla rodziców noworodka. O ile profesjonaliści mogą kierować się przede wszystkim oceną kliniczną stanu i rokowania noworodka w ocenie jego interesów, o tyle taka ocena przez rodziców musi wykraczać poza względy kliniczne. Ich sytuacja egzystencjalna, tj. ich osobiste zaangażowanie w decyzję oraz wyznawane przez nich wartości sprawiają, że nie mogą oni ograniczyć się do szacunków szans przetrwania dziecka. Muszą - ponieważ nie mają innego wyjścia - brać pod uwagę szerszy kontekst jego przyszłości. Z konieczności więc ich świadoma zgoda - o ile korzystają z rzetelnej lekarskiej oceny stanu klinicznego i rokowania ich dziecka - może być bardziej wiarygodna od decyzji innych osób. Opiera się ona na szerszej wiedzy i jest umieszczona w konkretnym kontekście ich rodziny.

Wynik namysłu rodziców w postaci świadomej zgody na postępowanie medyczne z noworodkiem na granicy zdolności do przeżycia może odbiegać od tego, co za właściwe uznają profesjonaliści medyczni. Jeżeli jednak decyzja rodziców nie jest sprzeczna z kliniczną oceną stanu pacjenta i rokowania oraz nie jest wyrazem przesądów lub uprzedzeń, profesjonaliści medyczni mają obowiązek respektowania ich świadomej decyzji o postępowaniu medycznym wobec ich dziecka nawet wtedy, gdy opinia lekarzy $\mathrm{w}$ tej sprawie jest odmienna.

\section{Bibliografia}

Anspach R.R. (1993), Deciding Who Lives: Fateful Choices in the Intensive-Care Nursery, University of California Press, Berkeley.

Archard D. (2003), Children, Family, and the State, Ashgate, Aldershot, Hants, Burlington, VT.

Bourillon A., Dehan M., Beaufils F., Fournier E. (1986), Incidence des facteurs d'environnement dans la décision éthique en réanimation pédiatrique, "Archives Françaises de Pédiatrie” 43 (suppl. 1): 563-568.

Brosig C.L., Pierucci R.L., Kupst M.J., Leuthner S.R. (2007), Infant End-of-Life Care: The Parents' Perspective, "Journal of Perinatology" 27 (8): 510-516.

Buchanan A.E., Brock D.W. (1989), Deciding for Others: The Ethics of Surrogate Decision Making, Cambridge University Press, New York.

Byrne S., Szyld E., Kattwinkel J. (2008), The Ethics of Delivery-Room Resuscitation, „Seminars in Fetal and Neonatal Medicine" 13 (6): 440-447.

Code de la santé publique. Version consolidée au 12 mars 2018.

${ }_{52}$ Por. Cuttini, Casotto, Orzalesi (2006); Orfali (2004); Orzalesi, Cuttini (2011). 
Cuttini M., Casotto V., Orzalesi M., Euronic Study Group (2006), Ethical Issues in Neonatal Intensive Care and Physicians' Practices: A European Perspective, „Acta Paediatrica Supplement" 95 (452): 42-46.

DeGrazia D. (1995), Value Theory and the Best Interests Standard, "Bioethics” 9 (1): 50-61.

Dehan M. (1997), L'éthique et sa pratique en neonatologie, [w:] Philosophie, éthique et droit de la médecine, J.-F. Mattéi, B. Feuillet-Le Mintier, D. Folscheid (red.), Presses Universitaires de France, Paris: 375-390.

Diekema D.S., Mercurio M.R., Adam M.B. (2011), Clinical Ethics in Pediatrics: A Case-Based Textbook, Cambridge University Press, Cambridge.

Duff R.S. (1987), "Close-Up" Versus "Distant" Ethics: Deciding the Care of Infants with Poor Prognosis, "Seminars in Perinatology" 11 (3): 244-253.

Elliston S. (2007), Best Interests of the Child in Healthcare (1st ed.), Routledge-Cavendish, New York.

Elster J. (1987), Solomonic Judgments: Against the Best Interest of the Child, „University of Chicago Law Review" 54 (1): 1-45.

Herring J. (2005), Farewell Welfare?, "Journal of Social Welfare and Family Law" 27 (2): 159-171.

K.k. Ustawa z dnia 6 czerwca 1997 r. - Kodeks karny. Dz.U. 1997 nr 88 poz. 553 z późn. zm.

K.r.o. Ustawa z dnia 25 lutego 1964 r. - Kodeks rodzinny i opiekuńczy, Dz.U. 1964 nr 9 poz. 59 z późn. zm.

KEL (2004), Kodeks etyki lekarskiej: tekst jednolity z dnia 2 stycznia 2004 r., zawierający zmiany uchwalone w dniu 20 września 2003 r. przez Nadzwyczajny VII Krajowy Zjazd Lekarzy (Biuletyn NRL 2004, nr 1, poz. 84), Naczelna Izba Lekarska, Warszawa.

Kipnis K. (2007), Harm and Uncertainty In Newborn Intensive Care, „Theoretical Medicine and Bioethics" 28 (5): 393-412.

Kopelman L.M. (1997), The Best-Interests Standard as Threshold, Ideal, and Standard of Reasonableness, "The Journal of Medicine and Philosophy” 22 (3): 271-289.

Kopelman L.M., Kopelman A.E. (2007), Using a New Analysis of the Best Interests Standard to Address Cultural Disputes: Whose Data, Which Values?, „Theoretical Medicine and Bioethics" 28 (5): 373-391.

Lantos J.D., Meadow W.L. (2006), Neonatal Bioethics: The Moral Challenges of Medical Innovation, Johns Hopkins University Press, Baltimore.

McHaffie H.E., Lyon A.J., Hume R. (2001), Deciding on Treatment Limitation for Neonates: The Parents' Perspective, „The European Journal of Pediatrics” 160 (6): 339-344.

Mnookin R.H. (1975), Child-Custody Adjudication: Judicial Functions in the Face of Indeterminacy, „Law and Contemporary Problems” 39 (Summer): 226-293.

Nguyen T.A.P., Ho L.Y. (2013), Review on Neonatal End-of-Life Decision-Making: Medical Authority or Parental Autonomy?, „Proceedings of Singapore Healthcare” 22 (2): 140-145.

Nuffield Council on Bioethics (2006), Critical Care Decisions in Fetal and Neonatal Medicine: Ethical Issues, URL = https://www.nuffieldbioethics.org/assets/pdfs/Critical-care-decisions.pdf [dostęp 24.02.2020].

Ong S.Y. (2013), The Ethics of Neonatal Resuscitation, „Proceedings of Singapore Healthcare” 22 (2): 99-102.

Orfali K. (2004), Parental Role in Medical Decision-Making: Fact or Fiction? A Comparative Study of Ethical Dilemmas in French and American Neonatal Intensive Care Units, „Social Science \& Medicine" 58 (10): 2009-2022.

Orzalesi M.M., Cuttini M. (2011), Ethical Issues in Neonatal Intensive Care, „Annali dell'Istituto Superiore di Sanità" 47 (3): 273-277. 
Polskie Towarzystwo Neonatologiczne (2017), Zasady postępowania w neonatologii przy podejmowaniu decyzji o objęciu opieka paliatywna uwzględniajace racje etyczne, wydanie II (2017) zaktualizowane i uzupełnione, [w:] Standardy opieki medycznej nad noworodkiem $w$ Polsce, M.K. Borszewska-Kornacka et.al. (red.), Polskie Towarzystwo Neonatologiczne, Warszawa.

Rhodes R., Holzman I.R. (2014), Is the Best Interest Standard Good for Pediatrics, „Pediatrics” 134 (suppl 2): 121-129.

Rutkowska M. (red.) (2011), Noworodek urodzony na granicy możliwości przeżycia. Część druga: Rekomendacje dotyczace postępowania z matka oraz noworodkiem urodzonym na granicy możliwości przeżycia z uwzględnieniem aspektów etycznych, „Medycyna Wieku Rozwojowego" 2/15 (3): 356-367.

Scanlon T. (1998), What We Owe to Each Other, Belknap Press of Harvard University Press, Cambridge, Mass.

Shah S. (2013), Does Research with Children Violate the Best Interests Standard? An Empirical and Conceptual Analysis, „Northwestern Journal of Law \& Social Policy” 8 (2): 121-173.

Shaw A. (1977), Defining the Quality of Life: A Formula Without Numbers, "Hastings Center Report" 7 (5): 11.

Sinclair J.C., Torrance G.W. (1995), The Use of Epidemiological Data for Prognostication and Decision Making, [w:] Ethics and Perinatology, A. Goldworth, W. Silverman, D.K. Stevenson, E.W.D. Young (red.), Oxford University Press, New York: 120-145.

Szewczyk K. (2010), Decyzje krytyczne w neonatologii i standardy ich podejmowania, „Diametros” 26: 96-135.

Szewczyk K. (2012), Czy rodzice powinni mieć prawo do decydowania o życiu i śmierci krytycznie chorych noworodków?, „Diametros” 34: 154-178.

U.p.p. Ustawa z dnia 6 listopada 2008 r. o prawach pacjenta i Rzeczniku Praw Pacjenta, tekst jedn. Dz.U. 2009 nr 52 poz. 417 z późn. zm.

U.z.l. Ustawa z dnia 5 grudnia 1996 r. o zawodach lekarza i lekarza dentysty, tekst jedn. Dz.U. 1997 nr 28 poz. 152 z późn. zm.

President's Commission for the Study of Ethical Problems in Medicine and Biomedical and Behavioral Research (1983), Deciding to Forego Life-Sustaining Treatment: A Report on the Ethical, Medical, and Legal Issues in Treatment Decisions. President's Commission for the Study of Ethical Problems in Medicine and Biomedical and Behavioral Research: For sale by the Supt. of Docs., U.S. G.P.O., Washington, DC.

Weir M., Evans M., Coughlin K. (2011), Ethical Decision Making in the Resuscitation of Extremely Premature Infants: The Health Care Professional's Perspective, "Journal of Obstetrics and Gynaecology Canada" 33 (1): 49-56.

Whitney S.N. (2005), The Extremely Premature Infant at the Crossroads: Ethical and Legal Considerations, [w:] Ethical Dilemmas in Pediatrics: Cases and Commentaries, L.R. Frankel, A. Goldworth, M.V. Rorty, W.A. Silverman (red.), Cambridge University Press, Cambridge, New York. 